\title{
Two views of the heart
}

\section{Sanjana Sreenath}

Texas Tech University Health Sciences Center, El Paso, TX, USA

Correspondence to: Sanjana Sreenath. Texas Tech University Health Sciences Center, El Paso, TX, USA. Email: sanjsund@ttuhsc.edu.

Submitted Feb 28, 2021. Accepted for publication Apr 16, 2021.

doi: $10.21037 / \mathrm{cdt}-21-125$

View this article at: http://dx.doi.org/10.21037/cdt-21-125

This series of digital paintings titled, "Two views of the heart," explores two ways of understanding the human heart. From a physics perspective, the heart is visualized as a pump driving blood flow through a closed circuit. Concepts of resistance, shear, stress, elasticity are frequently used in modeling fluid mechanics of the heart as well as Newtonian and Non-Newtonian blood flow through the vasculature. This view of the heart as an intricate, complex machine with various equations modeling its physiological mechanisms conjures up themes of mathematical modeling, scientific precision



Figure 1 Nodes, 2021. Digital. and technological advancement. The other humanistic view of the heart, as explored in literature and the medical humanities, looks at the broader context of what it means to be human.

The paintings primarily use lines or geometrical shapes in line with the heart as a complex machine but also preserves the structure of the human heart to underscore a more humanistic side. Medical practice is frequently described as the art of balancing scientific accuracy with a more personalized, humanistic touch. These paintings attempt to underscore that delicate balance (Figures 1-4).

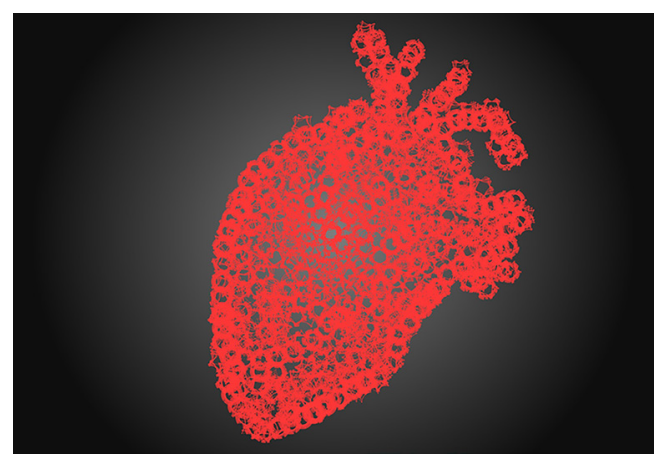

Figure 2 Polygonal, 2021. Digital. 


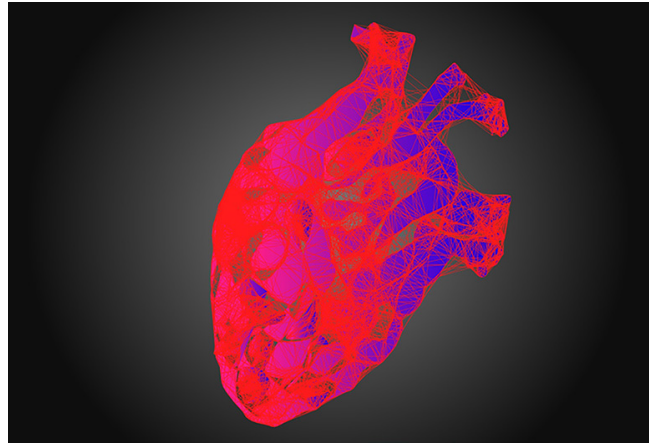

Figure 3 Venous web, 2021. Digital.

\section{Acknowledgments}

Funding: None.

\section{Footnote}

Provenance and Peer Review: This article was a standard submission to the journal. The article has undergone external peer review.

Conflicts of Interest: The author has completed the ICMJE uniform disclosure form (available at http://dx.doi. org/10.21037/cdt-21-125). The author has no conflicts of interest to declare.

Ethical Statement: The author is accountable for all



Figure 4 Cardinal Valves, 2021. Digital.

aspects of the work in ensuring that questions related to the accuracy or integrity of any part of the work are appropriately investigated and resolved.

Open Access Statement: This is an Open Access article distributed in accordance with the Creative Commons Attribution-NonCommercial-NoDerivs 4.0 International License (CC BY-NC-ND 4.0), which permits the noncommercial replication and distribution of the article with the strict proviso that no changes or edits are made and the original work is properly cited (including links to both the formal publication through the relevant DOI and the license). See: https://creativecommons.org/ licenses/by-nc-nd/4.0/.

Cite this article as: Sreenath S. Two views of the heart. Cardiovasc Diagn Ther 2021;11(5):1177-1178. doi: 10.21037/ cdt-21-125 